\title{
A temperatura da informação
}

Freqüentar congressos e cursos e ler artigos científicos é fundamental para a atualização do cirurgião-dentista. Esses dois meios diferem em sua essência e são complementares, não excludentes. Nenhum profissional deveria optar por apenas um deles, apesar da possível tentação de deixar de lado a leitura constante.

As duas formas demandam atitudes diferentes, que foram descritas há cerca de 40 anos por Marshall McLuhan como o "meio frio" e o "meio quente". O conceito original, na verdade, é uma visão de como se enquadram, respectivamente, televisão e mídia impressa na sociedade e pode ser transposto para a obtenção de informação em nossa área. A fonte de calor nesta metáfora é a atividade mental requerida na alquimia da leitura, que se contrapõe àquela de assistir a um curso.

O meio quente - ou seja, a leitura de artigos científicos - requer disciplina para a transposição de uma barreira imaginária, que é capacidade de entender um artigo e levá-lo para a prática clínica. A barreira só é vencida após a leitura esmerada de muitos artigos científicos e, a partir desse momento, $\mathrm{o}$ ato de ler se torna muito agradável e relativamente simples. A leitura é a obtenção da informação em primeira mão, nela reside o acesso ao estado da arte na ciência; e revistas científicas deveriam ser consumidas como outras mídias impressas, tendo lugar, por exemplo, na cabeceira da cama ou na mesa do consultório - ler é sempre prazeroso.

Em contrapartida, o meio frio - tal como cursos e conferências - oferece o calor do contato direto com autores e professores. Nele absorvemos parte da vivência de experts, entramos em suas vidas e tiramos delas sutilezas do conhecimento que somente o contato pessoal, a mímica facial e o olhar podem passar. Nesses encontros podemos confrontar diretamente os diversos conceitos de tratamento e trocar opiniões, com nossos pares, sobre os problemas que enfrentamos. Isso tudo com suavidade e pouca energia.

Um excepcional exemplo da importância desses encontros foi o $5^{\circ}$ Congresso Internacional de Ortodontia Dental Press. O encontro permitiu que os mais de 800 congressistas pudessem testemunhar um momento raro: alguns dos mais respeitados profissionais da Ortodontia brasileira apresentando seus trabalhos e debatendo sobre o tratamento da Classe II. O evento ainda foi abrilhantado pelo curso do Prof. James McNamara, que é responsável direto por procedimentos clínicos que muitos de nós executamos em nossos consultórios no tratamento dessa má oclusão.

$\mathrm{O}$ confronto entre as duas formas de atualização sublinha uma das evoluções que a Revista tem sofrido: o esfriamento da informação - sem perder a qualidade - para tornar mais agradável sua leitura. Leitores e autores poderão perceber que os artigos têm migrado para estilos redatoriais mais modernos. Temos diminuído a citação de autores no texto nos artigos - um velho hábito proveniente do argumento da autoridade - a fim de valorizar a evidência, a informação de qualidade. Apenas autores de estudos muito relevantes para o tópico do artigo devem ser citados. Nosso objetivo é otimizar o tempo dos leitores e diminuir a energia necessária para uma adequada leitura crítica.

O estilo moderno de se apresentar informações de qualidade pode ser amostrado, por exemplo, no Insight Ortodôntico, escrito pelo Prof. Consolaro, que apresenta uma excelente análise sobre os estudos a respeito da prescrição de analgésicos para pacientes em tratamento ortodôntico, e também na seção "O que há de novo", de autoria do Dr. Bósio.

A mesma tônica, informação de qualidade apresentada de forma agradável, pode ser conferida na entrevista com o Dr. Sarver, que teve como entrevistador o Dr. Gianelly, e também em outros artigos.

Como desgastar as superfícies proximais dos incisivos para solucionar apinhamentos e a estabilidade após a correção desse problema são mostrados em dois estudos que proporcionarão informações clínicas relevantes para os ortodontistas.

Quatro artigos tratam de problemas transversais de formas completamente diferentes e todos merecem ser lidos na integra. Os temas abordados se iniciam em uma nova proposta para a expansão maxilar na dentadura permanente, passam pela distração osteogênica sinfisária e terminam em dois estudos sobre o comportamento da sutura palatina mediana em diferentes métodos de expansão maxilar.

Trabalhos na área de materiais dentários tratam da força adesiva em diferentes protocolos de colagem (técnicas direta e indireta), dando informações para aplicação clínica direta.

Por fim, o Tópico Especial cobre um dos mais básicos exames complementares na Ortodontia: modelos de gesso. Básico tem como sinônimos fundamental, necessário, ou o que serve de base. Acredito que esse artigo poderá ser utilizado como referência por muitas clínicas radiológicas e clínicos, e ajudará a elevar a qualidade dos modelos produzidos em nosso país.

Boa leitura.

Jorge Faber Editor 